\title{
Public Perception of Climate Change in Yenagoa, Bayelsa State, Nigeria
}

\author{
Odafivwotu Ohwo \\ Department of Geography and Environmental Management, Faculty of Social Sciences, Niger Delta University, \\ Wilberforce Island, Bayelsa State 560103, Nigeria
}

Correspondence should be addressed to Odafivwotu Ohwo; drohwodafe@gmail.com

Received 28 July 2014; Revised 19 December 2014; Accepted 18 January 2015

Academic Editor: Yuanzhi Zhang

Copyright (C) 2015 Odafivwotu Ohwo. This is an open access article distributed under the Creative Commons Attribution License, which permits unrestricted use, distribution, and reproduction in any medium, provided the original work is properly cited.

This study was designed to assess the public perception of climate change in Yenagoa. The sample survey method was adopted, which involved the administration of 360 questionnaires to randomly selected households. The results showed that $43.33 \%$ of respondents lack adequate knowledge of climate change. Further interview revealed that $55.3 \%$ of the respondents are unaware that carbon dioxide $\left(\mathrm{CO}_{2}\right)$ is the major greenhouse gas, contributing about $55 \%$ to global warming. It was revealed that respondents' major sources of information on climate change were personal experience and television (66.33\%). Also, $48.7 \%$ of the respondents believed that one of the major natural causes of climate change is divine providence. The study also revealed that there were significant variations in respondents' perception of the causes, potential impacts, and mitigation strategies of climate change. The variations were attributable to differences in educational status and sources of information on climate change by respondents. The study concluded that the level of knowledge of the people was inadequate. Therefore, all stakeholders should step-up mass education and information sharing on the causes, potential impacts, and mitigation strategies of climate change.

\section{Introduction}

The Working Group 1 to the Fifth Assessment Report (AR5) of the Intergovernmental Panel on Climate Change [1] stated that "climate change refers to a change in the state of the climate that can be identified (e.g., by using statistical tests) by changes in the mean and/or the variability of its properties and that persists for an extended period typically decades or longer." The earlier conception of climate change generated a lot of commentary and debate among scientists and nonscientists alike, while some believed that global climate is changing others vehemently opposed the idea. This led to the development of several theories of the causes of climate change, which include terrestrial, astronomical, and extraterrestrial theories. All these theories of the possible causes of climate change either emphasized the role of factors external to the climate system or factors internal to it but mostly the latter. Extraterrestrial and astronomical theories of possible causes of climate change can be regarded as dealing with factors external to the climate system as they affect the amount of solar radiation which the earth as a planet is able to receive, that is, the amount of solar radiation incident on top of the earth's atmosphere. In contrast, the terrestrial theories of possible causes of climate change deal with the variations in the amount of solar radiation distribution over the earth's surface and between the earth's surface and its atmosphere [2]. Currently, the concern is that some of the internal factors may be humaninduced and may account for short-term variations in climate over the last century. Such human-induced changes include the emission of greenhouse gases and aerosols, changes in land use, and the depletion of the ozone layer through various human activities such as industrialization, urbanization, agriculture, and land clearance amongst others [2].

After several years of researches by scientists from the Intergovernmental Panel on Climate Change (IPCC) and other independent scientists, the emerging facts and data have brought about a general consensus by the scientific community that indeed the global climate is changing as 
a result of global warming, which is brought about by the increased volumes of carbon dioxide and other greenhouse gases released by the burning of fossil fuels, land clearing, agriculture, and other human activities. For example, a survey of thousands of peer-reviewed papers in scientific journals has found $97.1 \%$ agreed that climate change is caused by human activities. The survey considered the work of some 29,000 scientists published in 11,994 academic papers. Of the 4,000-plus papers that took a position on the causes of climate change, only $0.7 \%$ or 83 of those thousands of academic articles, disputed the scientific consensus that climate change is the result of human activities, with the view of the remaining $2.2 \%$ unclear [3]. This goes to show that the role of man as a potential agent of climate change cannot be ignored.

Human activities contribute to climate change by causing changes in earth's atmosphere in the amounts of greenhouse gases, aerosols (small particles), and cloudiness. The largest known contribution comes from the burning of fossil fuels, which releases carbon dioxide gas to the atmosphere. Greenhouse gases and aerosols affect climate by altering incoming solar radiation and out-going infrared (thermal) radiation that are part of earth's energy balance. Changing the atmospheric abundance or properties of these gases and particles can lead to a warming or cooling of the climate system.

The potential impacts of climate change cannot be over emphasized. Both the direct and indirect impacts of climate change have the potentials of causing serious environmental, health, and social-economic dislocations in most parts of the world especially in developing countries like Nigeria. Worldwide, climate change-related impacts including prolonged flooding, heat waves, drought, sea level rise, salinity, temperature, and rainfall variations have become evident [4]. People are directly exposed to changing weather patterns (temperature, precipitation, sea-level rise, and more frequent extreme events) and indirectly through changes in the quality of water, air, and food in addition to changes in ecosystems, agriculture, industry, human settlements, and the economy. These forms of direct and indirect exposure can lead to death, disability, and suffering $[5,6]$. The World Health Organization (WHO) has estimated that globally over 150,000 deaths annually result from changes in the world's climate, relative to the average from the baseline climate of 1961-1990 [7, 8].

Yenagoa is one of the Niger Delta coastal settlements, with an average height of below 15 metres above sea level. The topographical map of Bayelsa State indicates parts of Sabagrea and Yenagoa as places with land surfaces between 12 and 15.5 metres above sea level [9]. This has made the city susceptible to flooding and seriously threatened by sea level rise occasioned by global warming. In addition, the settlement is already under stress of demographic pressure and unsustainable oil exploitation activities. Global projections of sea level rise put the area under future inundation of up to $100 \mathrm{~km}$ inland. This was evident in the 2012 flood episode, which affected over 90 percent of the land area of Yenagoa. The implications are the loss of valuable biodiversity, land, property, economic activities, and livelihoods [10].
Though the impact is not expected to be uniform across board, the flora and fauna already enlisted as threatened will be more vulnerable. The poor, marginalized and economically weak inhabitants of Yenagoa would be worst affected. The impact would not be spontaneous and as such economic activities and facilities will gradually be relocated and human population will migrate, creating environmental refugees. The burden, which would probably be more social than economic, would be heavy on the government, the community, and other stakeholders. In addition, increasing scarcity of land will accelerate the stress on available resources and conflict could ensue [10].

Although many adaptive strategies can be developed to contend the negative impacts of climate change; adjustments are possible in practice within the limits of available income and technology. Various types of adaptation exist, for example, anticipatory and reactive, private and public, and autonomous and planned. Adaptive capacities are the ability of a system to adjust to climate change (including climate variability and extremes), to moderate potential damages, to take advantage of opportunities, or to cope with the consequences. There are individuals and groups within all societies that have insufficient capacity to adapt to climate change. The capacity to adapt is dynamic and influenced by economic and natural resources, social networks, entitlements, institutions and governance, human resources, and technology. Unfortunately, these basic requirements are poorly provided in Nigeria and the study area in particular.

From the above review, it is evident that several studies have been carried out on the science of climate change, which includes the causes, potential impacts, and mitigation and adaptation strategies by several authors and scientists. In spite of the progress made so far in the understanding of climate change, one may ask the following: How well informed is the public about these developments? Pam [11] provided an answer by stating that the concept of climate change is well known to the majority of those in the atmospheric science, but not so for many uneducated and even educated individuals in other disciplines. Hence, he called for studies on climate change education and awareness.

Actions to stem emissions of the gases that cause global warming are unlikely to approach what is needed until the public perceives that human-made climate change is underway and will have unacceptable consequences if effective actions are not taken to slow the climate change [12]. Similarly, [13] opined that improved understanding of public perceptions about global warming can contribute to inform scientific and policy discussions of climate change. Scientists need to know how the public is likely to respond to climate impacts or initiatives, because those responses can attenuate or amplify the impacts. They stated further that policy makers need to know what the public wants, in order to design policies that will be supported or at least tolerated. Both groups need to understand the extent to which people's responses will defer across regions. In the same vein [14] observed that much emphasis has been devoted to the science of climate change, but the education of the people and how they perceive the causes and impacts are lacking. 
Therefore, people's perception of climate change may be the most important factor determining their willingness to accept the scientific conclusion that humans are causing global warming [15]. This acceptance could be the key to positive behavioural changes, which would assist in the development and implementation of strategies in tackling the causes and impacts of climate change. Hence, this study is aimed at the determination of the public perception of the causes (natural and human), potential impacts, and mitigation strategies of climate change in Yenagoa.

\section{Method of Study}

This paper is designed to assess public perception of climate change in Yenagoa. In order to achieve this aim, the sample survey method was adopted, which involved obtaining information with the aid of questionnaire and oral interview from inhabitants of the metropolis. To avoid bias sampling of respondents, the metropolis was structured into twenty quarters that make up the metropolis, out of which twelve quarters were randomly selected for the study. In each of the selected twelve quarters, three streets were randomly selected and were assigned thirty (30) copies of the questionnaire, which represented 10 copies for each street, respectively, bringing the total to 360 copies. The systematic sampling technique at every five houses interval was used in the selection of the households where the copies of the questionnaire were administered. The questionnaire was administered directly to either the male or female head of the selected households who is willing to respond to the questionnaire. This was done with the aid of three research assistants who were dully instructed on the techniques of questionnaire administration. The questions in the questionnaire were used to assess the perception of respondents on the causes, impacts, and mitigation strategies of climate change, using the Likert scale (strongly agree, agree, disagree, strongly disagree, and cannot say). The social-demographic information of respondents was also obtained from the administered questionnaire.

The obtained data for the study were analyzed using both descriptive (tables and percentages) and inferential statistics (chi-square and Spearman's rank correlation). The descriptive statistics involved the presentation of the obtained data in tables, showing the various frequencies and calculated percentages. The chi-square test was used to determine whether there is significant difference in the respondents' perception of both the natural and human causes and potential impacts and mitigation strategies of climate change. A cross-over analysis was also undertaken using Spearman's rank correlation to determine the impact of respondents' educational status and major sources of information on their perception of both the natural and human causes, potential impacts, and mitigation strategies of climate change. The respondents' responses to the various perceived items of the causes, impacts, and mitigation strategies of climate change, with respect to their educational status and major sources of information, were, respectively, used to calculate Spearman's rank correlation coefficients using the E-View 7.0 statistical package.
TABLE 1: Sex distribution.

\begin{tabular}{lcc}
\hline Responses & Number of respondents & Percentage \\
\hline Male & 176 & 58.67 \\
Female & 124 & 41.33 \\
\hline Total & 300 & 100 \\
\hline
\end{tabular}

Source: Author’s fieldwork, 2014.

TABLE 2: Marital status.

\begin{tabular}{lcc}
\hline Responses & Number of respondents & Percentage \\
\hline Married & 167 & 55.67 \\
Single & 109 & 36.33 \\
Divorced & 13 & 4.33 \\
Widow/widower & 11 & 3.67 \\
\hline Total & 300 & 100 \\
\hline
\end{tabular}

Source: Author’s fieldwork, 2014.

TABLE 3: Educational qualification.

\begin{tabular}{lcc}
\hline Responses & Number of respondents & Percentage \\
\hline Postgraduate & 41 & 13.67 \\
Degree & 74 & 24.66 \\
NCE/OND & 53 & 17.67 \\
Secondary & 96 & 32.00 \\
Primary & 16 & 5.33 \\
No formal education & 20 & 6.67 \\
\hline Total & 300 & 100 \\
\hline
\end{tabular}

Source: Author’s fieldwork, 2014.

\section{Results and Discussion}

Out of the 360 administered questionnaires, 300 were returned representing $83.33 \%$. The sex distribution of respondents' comprises 176 (58.67\%) males and 124 (41.33\%) females. The marital status shows that there are 167 (55.67\%) who are married, 109 (36.33\%) are single, and 13 (4.33\%) are divorced, while widow/widower constitutes 11 (3.67\%) as revealed in Tables 1 and 2, respectively. Table 3 shows that $41(13.67 \%)$ respondents have postgraduate degrees and $74(24.66 \%)$ have first degree, while $53(17.67 \%), 96(32 \%)$, $16(5.33 \%)$, and $20(6.67 \%)$, respectively, have NCE/OND, secondary, primary, and no formal education. This response shows that the respondents are educated enough to provide answers to the questions on climate change. $\mathrm{A}$ fact that needed to be stressed is that $56 \%$ of the respondents attended tertiary education (OND/NCE and above), so the issues related to climate change may not be strange to them. In addition, a significant number of those with secondary, primary, and no formal education are above 30 years and are mostly engaged in occupations (farming and fishing) which are directly influenced by weather variability. Therefore, the issues related to climatic variability are not new to them.

The occupation with the highest respondents is civil service with $78(26 \%)$, students with $63(21 \%)$, and selfemployed with 70 (23.33\%), while private sector, farming and fishing, and others have 27 (9\%), 41 (13.67\%), and 21 (7\%) respondents, respectively (Table 4 ). 
TABle 4: Occupation.

\begin{tabular}{lcc}
\hline Responses & Number of respondents & Percentage \\
\hline Student & 63 & 21.00 \\
Civil service & 78 & 26.00 \\
Self-employed & 70 & 23.33 \\
Private sector & 27 & 9.00 \\
Farming and fishing & 41 & 13.67 \\
Others & 21 & 7.00 \\
\hline Total & 300 & 100 \\
\hline
\end{tabular}

Source: Author's fieldwork, 2014.

TABLE 5: Number of years living in Yenagoa.

\begin{tabular}{lcc}
\hline Responses & Number of respondents & Percentage \\
\hline $1-10$ years & 171 & 57.00 \\
$11-20$ years & 85 & 28.33 \\
$21-30$ years & 25 & 8.33 \\
Above 30 years & 19 & 6.33 \\
\hline Total & 300 & 100 \\
\hline
\end{tabular}

Source: Author's fieldwork, 2014.

TABLE 6: Major source of information on climate change.

\begin{tabular}{lcc}
\hline Responses & Number of respondents & Percentage \\
\hline Radio & 35 & 11.67 \\
Television & 85 & 28.33 \\
Newspaper & 10 & 3.33 \\
Lecture & 35 & 11.67 \\
Personal experience & 114 & 38.00 \\
Others & 21 & 7.00 \\
\hline Total & 300 & 100 \\
\hline
\end{tabular}

Source: Author's fieldwork, 2014.

TABLE 7: Knowledge of climate change.

\begin{tabular}{lcc}
\hline Responses & Number of respondents & Percentage \\
\hline Very adequate & 47 & 15.67 \\
Adequate & 123 & 41.00 \\
Inadequate & 102 & 34.00 \\
Very inadequate & 28 & 9.33 \\
\hline Total & 300 & 100
\end{tabular}

Source: Author's fieldwork, 2014.

Table 5 shows the number of years respondents have been living in Yenagoa. The responses show that over 42\% of the respondents have been living in Yenagoa for over 10 years. This is an indication that the respondents are familiar with the weather and climatic characteristics of Yenagoa and would have observed climatic variability over the years. This probably explained why $114(38 \%)$ of respondents indicated that their major source of information about climate change is personal experience (Table 6). This agreed with [16] report that all respondents' perceptions of climate variability are largely drawn from proxy indicators like production losses, poor growth of crops, increased sickness, and the shared
TABLE 8: Major greenhouse gases that cause human-induced climate change.

\begin{tabular}{lcc}
\hline Greenhouse gas & Number of respondents & Percentage \\
\hline Methane & 27 & 9.0 \\
Nitrous oxide & 18 & 6.0 \\
Carbon dioxide & 134 & 44.7 \\
Halocarbons & 18 & 6.0 \\
None of the above & 11 & 3.7 \\
No idea & 92 & 30.6 \\
\hline Total & 300 & 100 \\
\hline
\end{tabular}

Source: Author's fieldwork, 2014.

experiences of other members of the community. However, $35(11.67 \%), 85(28.33 \%)$, and $10(3.33 \%)$ respondents, respectively, indicated radio, television, and newspapers. On the other hand, 35 (11.67\%) and 21 (7\%) respondents indicated lecture and other sources, respectively. Majority of those who indicated lecture are students' respondents. The major sources of information on climate change indicated by the respondents probably accounts for $43.33 \%$ indicating poor knowledge of climate change (Table 7). As a matter of fact, personal experience alone may not be sufficient to have adequate knowledge of the causes and impacts of climate change. Also, both radio and television sources of information on climate change may not be regular and detailed because of the few minutes or hours given to most programmes on television and radio. While only $3.33 \%$ respondents indicated print media. This is so because of the cost of purchase of newsprints, which are beyond the reach of the average respondent.

Although 56.67\% respondents indicated adequate knowledge, only $15.67 \%$ indicated very adequate knowledge of climate change. This percentage is quite low and is in conformity with a similar study, which reported $22 \%$ of urban awareness in the Niger Delta region [15]. An interaction with some of the respondents that claimed adequate knowledge actually revealed that they have poor knowledge of the causes and impacts of climate change. For example, 166 (55.3\%) of the respondents do not know that carbon dioxide is the major greenhouse gas that causes human-induced climate change. The distribution of the responses show that 27 (9\%) indicated methane and $18(6 \%)$ indicated nitrous oxide, while another $18(6 \%), 11(3.7 \%)$, and $92(30.6 \%)$, respectively, indicated halocarbons, none of the above, and no idea (Table 8). This awareness level would definitely affect climate change adaptability and mitigation strategies in Yenagoa.

\subsection{Perceived Major Natural and Human Causes of Climate} Change. The limited knowledge of respondents was also revealed when they were asked about the major natural causes of climate change. For instance, $48.7 \%$ of respondents believe that divine providence (act of God) was one of the major causes of climate change, while $26 \%$ of them strongly agreed, and $22.7 \%$ agreed (Table 9). This response is similar to what [15] reported, where $31 \%$ of the respondents stated that climate change was an act of God. This is a clear ignorance 
TABle 9: Perceived major natural causes of climate change.

\begin{tabular}{lccccccccccc}
\hline S/N & Natural cause & SA & $\%$ & A & $\%$ & D & $\%$ & SD & $\%$ & CS & $\%$ \\
\hline 1 & Volcanic activities & 89 & 29.7 & 94 & 31.3 & 54 & 18.0 & 7 & 2.3 & 56 & 18.7 \\
2 & $\quad$ Solar output & 63 & 21.0 & 92 & 30.6 & 78 & 26.0 & 9 & 3.0 & 58 & 19.3 \\
3 & $\begin{array}{c}\text { Changes on earth's orbit } \\
\text { around the sun } \\
\text { Divine providence (act } \\
\text { of God) }\end{array}$ & 49 & 16.3 & 86 & 28.7 & 73 & 24.3 & 19 & 6.3 & 73 & 24.3 \\
4 & 78 & 26.0 & 68 & 22.7 & 63 & 21.0 & 15 & 5.0 & 76 & 25.3 \\
\hline
\end{tabular}

$\mathrm{SA}=$ strongly agreed, $\mathrm{A}=$ agreed, $\mathrm{D}=$ disagreed, $\mathrm{SD}=$ strongly disagreed and $\mathrm{CS}=$ cannot say.

Source: Author's fieldwork, 2014.

TABle 10: Perceived major human causes of climate change.

\begin{tabular}{|c|c|c|c|c|c|c|c|c|c|c|c|}
\hline $\mathrm{S} / \mathrm{N}$ & Human cause & SA & $\%$ & A & $\%$ & $\mathrm{D}$ & $\%$ & $\mathrm{SD}$ & $\%$ & CS & $\%$ \\
\hline 1 & The burning of fossil fuels & 184 & 61.3 & 99 & 33.0 & 7 & 2.3 & 0 & 0.0 & 10 & 3.3 \\
\hline 2 & Urbanization & 91 & 30.3 & 130 & 43.3 & 46 & 15.3 & 7 & 2.3 & 26 & 8.7 \\
\hline 3 & Water pollution & 99 & 33.0 & 121 & 40.3 & 41 & 13.7 & 9 & 3.0 & 30 & 10.0 \\
\hline 4 & Deforestation & 149 & 49.7 & 86 & 28.7 & 36 & 12.0 & 12 & 4.0 & 17 & 5.7 \\
\hline 5 & Ozone layer depletion & 159 & 53.0 & 93 & 31.0 & 9 & 3.0 & 4 & 1.3 & 35 & 11.7 \\
\hline 6 & Gas flaring & 151 & 50.3 & 110 & 36.7 & 17 & 5.7 & 12 & 4.0 & 10 & 3.3 \\
\hline 7 & Industrialization & 133 & 44.3 & 112 & 37.3 & 21 & 7.0 & 11 & 3.7 & 23 & 7.7 \\
\hline
\end{tabular}

$\mathrm{SA}=$ strongly agreed, $\mathrm{A}=$ agreed, $\mathrm{D}=$ disagreed, $\mathrm{SD}=$ strongly disagreed, and $\mathrm{CS}=$ cannot say.

Source: Author's fieldwork, 2014.

of the known scientific natural causes (volcanic eruption, solar output, and the earth's orbit around the sun) of climate change. This response pattern is not surprising because most Nigerians are very religious people. Certain natural processes they do not understand are easily explained off as divine providence. This kind of mindset could hamper measures designed to tackle the impacts of climate change. In addition, $25.3 \%$ of respondents cannot say whether climate change is as a result of divine providence or not. Furthermore, 39\% of respondents are not aware that volcanic activities are major natural causes of climate change. Similarly, $48.3 \%$ and $54.9 \%$ of respondents do not know that solar output and earth's orbit around the sun are, respectively, major natural causes of climate change (Table 9). In a similar study of "Public Perception of Climate Change in Wales," only 52\% of the respondents believe in the natural and human components to climate change causation [17]. One of the major reasons for the poor knowledge of natural causes of climate change is probably the major sources of information (radio and television) on climate change, which mainly emphasized the anthropogenic factors.

Unlike the responses to the major natural causes of climate change, respondents are more aware of the anthropogenic (human-induced) causes of climate change as revealed in Table 10. For instance, 283 (94.3\%) of respondents are aware that the burning of fossil fuels is a major cause of human-induced climate change. Of this number, $61.3 \%$ strongly agreed, while $33 \%$ agreed. Only 17 (5.6\%) respondents are ignorant of the burning of fossil fuel as a human-induced cause of climate change. Similarly, 73.6\%, $73.3 \%$, and $78.4 \%$ respondents perceived urbanization, water pollution, and deforestation as major human causes of climate change, respectively. In a similar vein, $84 \%, 87 \%$, and $81.6 \%$ of respondents strongly agreed and agreed that ozone layer depletion, gas flaring, and industrialization are equally major causes of human-induced climate change, respectively (Table 10). Although gas flaring has not been identified at a global scale as responsible for climate change, respondents were able to identify the local causal factor of atmospheric carbon concentration and pollution in Bayelsa State, which is an oil producing state in Nigeria, where gas flaring is still very predominant. Studies have shown, however, that the impact of gas flaring is localized and statistically insignificant $20 \mathrm{~km}$ from the flare sites $[18,19]$. Although respondents were able to identify the major scientific causes of human-induced climate change, majority of those interviewed do not know how these human activities cause climate change. For example, some respondents do not know that water bodies and forests act as carbon sinks, which help to reduce the amount of carbon dioxide emitted into the atmosphere and that polluting water bodies and deforestation can enhance the amount of carbon in the atmosphere.

3.2. Perceived Potential Impacts of Climate Change. Scientific investigations have identified temperature increases, sea level rise, flooding, health challenges, melting ice, irregular precipitation patterns, and desertification, amongst others as potential impacts of climate change [20,21]. Yenagoa is a coastal city in the Niger Delta; therefore, the impact of climate change can easily be noticed in the area. Hence, respondents were able to perceive the potential impact of climate change in Yenagoa, based on their personal experiences of climatic 
TABLE 11: Perceived potential impacts of climate change.

\begin{tabular}{|c|c|c|c|c|c|c|c|c|c|c|c|}
\hline $\mathrm{S} / \mathrm{N}$ & Impact & SA & $\%$ & A & $\%$ & $\mathrm{D}$ & $\%$ & $\mathrm{SD}$ & $\%$ & CS & $\%$ \\
\hline 1 & Temperature increases & 158 & 52.7 & 120 & 40.0 & 11 & 3.7 & 0 & 0.0 & 11 & 3.7 \\
\hline 2 & Sea level rise and flooding & 102 & 34.0 & 144 & 48.0 & 27 & 9.0 & 5 & 1.7 & 22 & 7.3 \\
\hline 3 & Increase health challenges & 103 & 34.3 & 140 & 46.7 & 26 & 8.7 & 12 & 4.0 & 19 & 6.3 \\
\hline 4 & Ecological dislocations & 118 & 39.3 & 95 & 31.7 & 15 & 5.0 & 9 & 3.0 & 63 & 21.0 \\
\hline 5 & Increase agricultural challenges & 117 & 39.0 & 126 & 42.0 & 26 & 8.7 & 7 & 2.3 & 24 & 8.0 \\
\hline 6 & Melting of ice & 96 & 32.0 & 106 & 35.3 & 24 & 8.0 & 13 & 4.3 & 61 & 20.3 \\
\hline 7 & Coastal inundation & 70 & 23.3 & 104 & 34.7 & 32 & 10.7 & 9 & 9.0 & 85 & 28.3 \\
\hline 8 & Desertification and drought & 91 & 30.3 & 124 & 41.3 & 20 & 6.7 & 18 & 6.0 & 47 & 15.7 \\
\hline 9 & Changes in precipitation pattern & 102 & 34.0 & 149 & 49.7 & 18 & 6.0 & 4 & 1.3 & 27 & 9.0 \\
\hline
\end{tabular}

$\mathrm{SA}=$ strongly agreed, $\mathrm{A}=$ agreed, $\mathrm{D}=$ disagreed, $\mathrm{SD}=$ strongly disagreed, and $\mathrm{CS}=$ cannot say.

Source: Author's fieldwork, 2014.

variability, since $43 \%$ of them have been living in the city for over 10 years (Table 5 ).

Respondents are convinced that the temperature of Yenagoa has increased. In fact, $52.7 \%$ and $40 \%$ of the respondents, respectively, strongly agreed and agreed that temperature in the city has increased (Table 11). Those interviewed claim that they can hardly sleep well at night these days without fan or air conditioner because of sweating as a result of increased temperature, most especially during the dry season, which was not the case in the past. This agrees with [16] that $95 \%$ of respondents' in their study reported that heat during the summer has increased, while $65 \%$ reported that winter temperatures were warmer than their previous experiences. This claim is supported by scientific studies, which estimated that the earth's temperature has increased by 0.3 to $1.1^{\circ} \mathrm{C}$ since 1900 [2]. More specifically, [22] observed that in Nigeria the temperature increase is $1.1^{\circ} \mathrm{C}$ since 1901 , while that of the globe is $0.74^{\circ} \mathrm{C}$ since 1860 . If the increase in average global temperature experienced in the last few decades continues unabated, it may lead to, among other things, a rise in the average sea level as a result of melting of polar ice and glacier and the thermal expansion of ocean water. In addition, global warming may result in significant changes in the distribution of precipitation worldwide [2]. This is currently the situation in Yenagoa where there are noticeable changes in precipitation pattern according to the respondents. The responses show that $34 \%$ and $49.7 \%$ respondents strongly agreed and agreed, respectively, that precipitation patterns have changed over the years in terms of duration and intensity (Table 11).

The flood episode of 2012, which engulfs over $90 \%$ of Yenagoa and most coastal settlements of Nigeria, was attributed partly to climate change, resulting from sea level rise and unpredictable precipitation pattern by environmentalists, government agencies, and other stakeholders. This probably explains why $82 \%$ of the respondents perceived sea level rise and flooding as potential impacts of climate change. Specifically, $34 \%$ and $48 \%$ of the respondents strongly agreed and agreed, respectively, while only $9 \%, 1.7 \%$, and $7.3 \%$ respondents disagreed, strongly disagreed, and cannot say, respectively (Table 11). The unpredictable precipitation pattern in Yenagoa and flood episodes have posed serious challenges to agricultural practices, which have impacted negatively on the level of productivity. Although models project that agricultural production on the global scale will not be significantly affected, significant regional changes in productivity are projected. Agricultural models project productivity losses of up to $30 \%$ in a doubled carbon dioxide world in Africa and Latin America, where hunger and famine already exist today [23]. These projections are in line with what farmers are currently experiencing as revealed by interviewed respondents who are farmers. Hence, $81 \%$ of the respondents strongly agreed and agreed that climate change increases agricultural challenges (Table 11).

A warmer world is projected to lead to a significant increase in the incidence of heat-stress mortality in cities and even more importantly to an increase in the incidence of vector-borne diseases such as malaria and dengue. Currently, there are over 300 million new cases of malaria per year, with over 2 million deaths. An increase in surface temperatures of $3-4^{\circ} \mathrm{C}$ could increase the incidence of malaria by about $25 \%$ and extend the geographic range of potential transmission [23]. Since Yenagoa is located in the tropics, where malaria is so prevalent, respondents believe that climate change could exacerbate the incidence of malaria and other diseases in the area, as the environment becomes friendlier to the rapid breeding of the vector-borne diseases. This explains why $81 \%$ of respondents strongly agreed and agreed that climate change increases health challenges (Table 11). Respondents are quite familiar with the potential impacts of climate change. This can be partly explained by their direct experiences of most of these potential impacts in Yenagoa, which is a coastal settlement and located in the tropics, where most of the potential impacts have been projected to be very severe. Table 11 also shows that $71 \%, 67.3 \%, 58 \%$, and $71.6 \%$ respondents either strongly agreed or agreed, respectively, that ecological dislocation, melting of ice, coastal inundation, and desertification and drought are potential impacts of climate change. These potential impacts are well documented in the literature.

3.3. Climate Change Mitigation Strategies. Mitigation strategies are measures taken to deal with the causes of climate 
TABLE 12: Perceived climate change mitigation strategies.

\begin{tabular}{|c|c|c|c|c|c|c|c|c|c|c|c|}
\hline $\mathrm{S} / \mathrm{N}$ & Human action & SA & $\%$ & A & $\%$ & $\mathrm{D}$ & $\%$ & SD & $\%$ & CS & $\%$ \\
\hline 1 & Reduce the burning of fossil fuels & 188 & 62.7 & 98 & 32.7 & 0 & 0.0 & 0 & 0.0 & 14 & 4.7 \\
\hline 2 & Tree planting & 157 & 52.3 & 118 & 39.3 & 10 & 3.3 & 3 & 1.0 & 12 & 4.0 \\
\hline 3 & Stop deforestation & 145 & 48.3 & 127 & 42.3 & 11 & 3.7 & 2 & 0.7 & 15 & 5.0 \\
\hline 4 & Use of renewable energy & 91 & 30.3 & 126 & 42.0 & 31 & 10.3 & 4 & 1.3 & 48 & 16.0 \\
\hline
\end{tabular}

$\mathrm{SA}=$ strongly agreed $\mathrm{A}=$ agreed, $\mathrm{D}=$ disagreed, $\mathrm{SD}=$ strongly disagreed, and $\mathrm{CS}=$ cannot say.

Source: Author's fieldwork, 2014.

change [2]. Mitigation measures are therefore actions taken by man to prevent or retard the increase of greenhouse gases concentration in the atmosphere. This may be achieved by limiting current and future emissions from man-made sources of greenhouse gases and by enhancing the potential sinks of greenhouse gases. As noted earlier, the major greenhouse gases are carbon dioxide $\left(\mathrm{CO}_{2}\right)$, chlorofluorocarbons (CFCs), methane $\left(\mathrm{CH}_{4}\right)$, and nitrous oxide $\left(\mathrm{N}_{2} \mathrm{O}\right)$, which contributes by $55 \%, 24 \%, 15 \%$, and $6 \%$, respectively, to global warming [2]. Therefore, any meaningful mitigation strategy on climate change must focus on the reduction of these greenhouse gases emissions into the atmosphere. Some of the effective ways of achieving this goal are the reduction in the burning of fossil fuels such as coal and oil, tree planting and stoppage of deforestations, and use of renewable energy.

Responses to these human actions to climate change mitigation show that respondents are aware of the major ways of combating global warming. Hence, $95.4 \%$ of respondents either strongly agreed or agreed that the reduction in the burning of fossil fuels could mitigate climate change. Similarly, $91.6 \%, 90.6 \%$, and $72.3 \%$ either strongly agreed or agreed that tree planting, stoppage of deforestation, and use of renewable energy could, respectively, mitigate climate change (Table 12). However, in spite of this response pattern, an interaction with some of these respondents shows that they are not well informed on how, for example, tree planting reduces climate change. According to this category of respondents they have heard it on radio or television by government that it is the right way to go in sustaining the environment.

The salient points of the findings can be summarized as follows:

(i) A significant percentage of the respondents do not have adequate knowledge of climate change. For example, 166 (55.3\%) of the respondents do not know that carbon dioxide is the major greenhouse gas that causes human-induced climate change.

(ii) Respondents are more aware of the anthropogenic causes of climate change. For instance, $48.7 \%$ of the respondents believed that one of the major natural causes of climate change is divine providence (act of God).

(iii) Respondents are able to perceive the potential impacts of climate change, based on their personal experiences of climatic variability in Yenagoa, which is a coastal city in the Niger Delta, where the impact of climate change can easily be noticed, as $43 \%$ of them have been living in the city for over 10 years. (iv) Although respondents are aware of some of the effective mitigation strategies of climate change, they do not know how these activities, for example, tree planting reduces climate change. They only heard it in the mass media as the right way to go in sustaining the environment.

\subsection{Statistical Analyses of the Perceived Natural and Human} Causes, Potential Impacts, and Mitigation Strategies of Climate Change. In order to determine whether there are significant differences in the perception of the causes, potential impacts, and mitigation strategies of climate change, the chi-square test was calculated using the data in Tables 9-12, respectively. The analyses revealed that there are significant differences in respondents' perception of the causes, impacts, and mitigation strategies of climate change, as the calculated chi-square values are, respectively, higher than the respective table values as shown in Table 13. In order to determine the sources of the variations, a further cross-over analysis (Spearman's rank correlation) was carried out using the parameters of educational status and major sources of information as they influence respondents' perception of climate change. The results of the analyses are presented in a correlation matrix as shown in Tables 14-21. From the results, it is evident that both the educational status and sources of information of respondents on climate change affect their perception. For instance, those with tertiary education (Postgraduate, degree, and NCE/OND) perceived both natural and human causes, potential impacts, and mitigation strategies of climate change similarly, as the correlation coefficient ranges from 0.712 to 0.975 . The lowest value of 0.712 was calculated for respondents with degree and NCE/OND perception of the natural causes of climate change, while the highest value of 0.975 was for respondents with postgraduate and degree perception of the mitigation strategies of climate change. On the other hand, the $r$ values of respondents with tertiary education and other educational groups range from -0.030 to 0.922 . The lowest value was calculated for respondents with postgraduate and primary education perception of the natural causes of climate change, while the highest value was for NCE/OND and secondary education respondents' perception of the human causes of climate change.

The sources of information of respondents on climate change also influence their perception. The $r$ values as presented in Tables 18-21 show that there is a strong relationship in the perception of respondents who obtain their information from formal media (radio, television, newspaper, 
TABLE 13: Chi-square analyses.

\begin{tabular}{|c|c|c|c|c|c|}
\hline Item & Calculated value & Degree of freedom & Table value & Significance level & Remark \\
\hline Perceived major natural causes of climate change & 35.2 & 12 & 21.03 & 0.05 & Significant \\
\hline Perceived major human causes of climate change & 174.41 & 24 & 36.42 & 0.05 & Significant \\
\hline Perceived potential impacts of climate change & 234.54 & 32 & 43.77 & 0.05 & Significant \\
\hline Perceived climate change mitigation strategies & 121.16 & 12 & 21.03 & 0.05 & Significant \\
\hline
\end{tabular}

TABLE 14: Spearman's rank correlation of different educational groups perception of the natural causes of climate change.

\begin{tabular}{|c|c|c|c|c|c|c|}
\hline & Postgraduate & Degree & NCE/OND & Secondary & Primary & No formal edu. \\
\hline Postgraduate & 1.000 & & & & & \\
\hline Degree & 0.898 & 1.000 & & & & \\
\hline NCE/OND & 0.712 & 0.706 & 1.000 & & & \\
\hline Secondary & 0.553 & 0.328 & 0.608 & 1.000 & & \\
\hline Primary & -0.030 & -0.084 & 0.009 & 0.303 & 1.000 & \\
\hline No formal education & -0.389 & -0.437 & 0.0673 & 0.357 & 0.349 & 1.000 \\
\hline
\end{tabular}

TABLE 15: Spearman's rank correlation of different educational groups perception of the human causes of climate change.

\begin{tabular}{|c|c|c|c|c|c|c|}
\hline & Postgraduate & Degree & NCE/OND & Secondary & Primary & No formal edu. \\
\hline Postgraduate & 1.000 & & & & & \\
\hline Degree & 0.961 & 1.000 & & & & \\
\hline NCE/OND & 0.949 & 0.945 & 1.000 & & & \\
\hline Secondary & 0.930 & 0.914 & 0.922 & 1.000 & & \\
\hline Primary & 0.705 & 0.434 & 0.463 & 0.364 & 1.000 & \\
\hline No formal education & 0.249 & 0.548 & 0.322 & 0.314 & 0.854 & 1.000 \\
\hline
\end{tabular}

TABLE 16: Spearman's rank correlation of different educational groups perception of the potential impacts of climate change.

\begin{tabular}{|c|c|c|c|c|c|c|}
\hline & Postgraduate & Degree & NCE/OND & Secondary & Primary & No formal edu. \\
\hline Postgraduate & 1.000 & & & & & \\
\hline Degree & 0.939 & 1.000 & & & & \\
\hline NCE/OND & 0.812 & 0.825 & 1.000 & & & \\
\hline Secondary & 0.512 & 0.616 & 0.742 & 1.000 & & \\
\hline Primary & 0.811 & 0.137 & 0.300 & 0.430 & 1.000 & \\
\hline No formal education & 0.113 & 0.233 & 0.342 & 0.581 & 0.785 & 1.000 \\
\hline
\end{tabular}

TABLE 17: Spearman's rank correlation of different educational groups perception of mitigation strategies of climate change.

\begin{tabular}{|c|c|c|c|c|c|c|}
\hline & Postgraduate & Degree & NCE/OND & Secondary & Primary & No formal edu. \\
\hline Postgraduate & 1.000 & & & & & \\
\hline Degree & 0.975 & 1.000 & & & & \\
\hline NCE/OND & 0.925 & 0.899 & 1.000 & & & \\
\hline Secondary & 0.830 & 0.780 & 0.858 & 1.000 & & \\
\hline Primary & 0.232 & 0.204 & 0.295 & 0.449 & 1.000 & \\
\hline No formal education & 0.456 & 0.417 & 0.544 & 0.502 & 0.430 & 1.000 \\
\hline
\end{tabular}

TABLE 18: Spearman's rank correlation of respondents' sources of information on the perception of the natural causes of climate change.

\begin{tabular}{lccccc}
\hline & Radio & Television & Newspaper & Lecture & Per. exp. \\
\hline Radio & 1.000 & & & & \\
Television & 0.590 & 1.000 & & & \\
Newspaper & 0.628 & 0.670 & 1.000 & & \\
Lecture & 0.840 & 0.598 & 0.613 & 1.000 & 1.000 \\
Personal Experience & 0.411 & 0.024 & 0.280 & -0.061 & 0.765 \\
Others & -0.041 & 0.038 & 0.357 & -0.166 & 1.000 \\
\hline
\end{tabular}


TABLE 19: Spearman's rank correlation of respondents' sources of information on the perception of the human causes of climate change.

\begin{tabular}{lccccc}
\hline & Radio & Television & Newspaper & Lecture & Per. exp. \\
\hline Radio & 1.000 & & & & \\
Television & 0.948 & 1.000 & & & \\
Newspaper & 0.872 & 0.863 & 1.000 & & \\
Lecture & 0.889 & 0.863 & 0.915 & 1.000 & 1.000 \\
Personal Experience & 0.868 & 0.847 & 0.812 & 0.809 & 0.667 \\
Others & 0.656 & 0.644 & 0.613 & 0.613 & 1.000 \\
\hline
\end{tabular}

TABLE 20: Spearman's rank correlation of respondents' sources of information on the perception of the potential impacts of climate change.

\begin{tabular}{|c|c|c|c|c|c|c|}
\hline & Radio & Television & Newspaper & Lecture & Per. exp. & Others \\
\hline Radio & 1.000 & & & & & \\
\hline Television & 0.948 & 1.000 & & & & \\
\hline Newspaper & 0.888 & 0.883 & 1.000 & & & \\
\hline Lecture & 0.917 & 0.829 & 0.903 & 1.000 & & \\
\hline Personal Experience & 0.663 & 0.760 & 0.646 & 0.644 & 1.000 & \\
\hline Others & 0.360 & 0.458 & 0.356 & 0.320 & 0.749 & 1.000 \\
\hline
\end{tabular}

TABLE 21: Spearman's rank correlation of respondents' sources of information on the perception of mitigation strategies of climate change.

\begin{tabular}{lccccc}
\hline & Radio & Television & Newspaper & Lecture & Per. Exp. \\
\hline Radio & 1.000 & & & & \\
Television & 0.993 & 1.000 & & & \\
Newspaper & 0.930 & 0.897 & 1.000 & & \\
Lecture & 0.927 & 0.908 & 0.940 & 1.000 & 1.000 \\
Personal Experience & 0.827 & 0.861 & 0.721 & 0.843 & 0.937 \\
Others & 0.844 & 0.853 & 0.769 & 0.713 & 1.000 \\
\hline
\end{tabular}

and lecture) as opposed to those who relied on personal experience and other means of information on climate change. For example, the correlation among the various formal media sources of information ranges from 0.590 to 0.993 , while the correlation between the formal media and personal experience and other means of communication range from 0.024 to 0.868 . This shows that the perceptions of those that obtained information about climate change through the formal media (radio, television, newspaper, and lecture) are similar but different from those of personal experience and other means of information.

\section{Conclusion}

The study assessed the perception of inhabitants of Yenagoa on the causes, potential impacts, and mitigation strategies of climate change. The study revealed that $43.33 \%$ of respondents describe their knowledge of climate change as either inadequate or very inadequate. Even those that claimed to have either very adequate or adequate knowledge actually have poor knowledge on further interview. This is evident from their responses to the major greenhouse gas that causes human-induced climate change. The responses indicated that $55.3 \%$ of the respondents are not aware that carbon dioxide $\left(\mathrm{CO}_{2}\right)$ is the major greenhouse gas, contributing about $55 \%$ to global warming. Similarly, $48.7 \%$ of the respondents believed that one of the major natural causes of climate change is divine providence (act of God).

The major sources of information on climate change as indicated by respondents are personal experience (38\%), television $(28.33 \%)$, radio and lecture $(11.67 \%)$, respectively. Those that indicated personal experiences on further interview were actually referring to climatic variability not climate change. The study also revealed that respondents are more familiar with the anthropogenic causes, impacts, and mitigation strategies of climate change than the natural causes. In spite of this awareness level, a significant number of the respondents do not know how some of these factors, processes, and strategies operate in nature. All they know is that the government and other stakeholders have said these things on the mass media (radio and television) as the right way to go in maintaining a sustainable environment. Hence, the chi-square test revealed that there are significant differences in the perception of climate change by the respondents. These differences were attributable to the different educational status and sources of information of respondents on climate change.

Based on the perception of inhabitants of Yenagoa on the causes, potential impacts, and mitigation strategies of climate change, it can be concluded that the level of knowledge of the people is still inadequate. It is therefore recommended that the government, mass media (radio and television), 
NGOs, environmental right activists, and other stakeholders should step-up mass education and information sharing on the causes, potential impacts, and mitigation strategies of climate change. Since $40 \%$ of the respondents indicated the mass media (radio and television) as their major source of information on climate change, there is the need for these media outfits to deliberately develop more programmes that are directed to issues of climate change. Furthermore, the issues of climate change and sustainable environmental management should be incorporated into the General Studies (GST) courses at the undergraduate level and geography and social studies subjects at both the secondary and primary school levels, respectively. If the people are well informed on these issues it would be easier for the people to key into government plans in mitigating climate change. In addition, it will make the people imbibe positive behavioural changes that would help to save planet earth and achieve sustainable socioeconomic and environmental management.

\section{Conflict of Interests}

The author declares that there is no conflict of interest regarding the publication of this paper.

\section{References}

[1] Intergovernmental Panel on Climate Change, "Introduction," in Climate Change 2013: The Physical Science Basis, Contribution of Working Group 1 to the Fifth Assessment Report of the Intergovernmental Panel on Climate Change, 2013.

[2] J. O. Ayoade, Climate Change, Vantage Publishers, Ibadan, Nigeria, 2003.

[3] The Guardian, 2013, http://www.theguardian.com/environment/ 2013/May/16/climate-research-nearly-unanimous-humans-causes.

[4] United Nations Development Programme, Human Development Report. Background Paper on Risks, Vulnerability and Adaptation in Bangladesh, UNDP, 2007.

[5] A. Rahman, "Climate change and its impact on health in Bangladesh," Regional Health Forum, vol. 12, no. 1, pp. 16-26, 2008.

[6] S. Shahid, "Probable impacts of climate change on public health in Bangladesh," Asia-Pacific Journal of Public Health, vol. 22, no. 3, pp. 310-319, 2010.

[7] World Health Organization, Health and Environmental Linkage Initiative. Climate Change: Deaths from Climate Change, World Health Organization, Geneva, Switzerland, 2011.

[8] A. J. McMichael and C. D. Butler, "Health promotion challenges: emerging health issues: the widening challenge for population health promotion," Health Promotion International, vol. 21, no. 1, pp. 15-24, 2007.

[9] C. U. Oyugun, "Climate, relief and drainage," in The Land and People of Bayelsa State: Central Niger Delta, E. J. Alagoa, Ed., pp. 31-43, Research Publications, Port Harcourt, Nigeria, 1999.

[10] C. O. Ogba and P. B. OUtang, Vulnerability and Adaptations of Nigeria's Niger Delta Coast Settlements to Sea Level Rise, TS 7B Coastal Zone Management and Environmental Issues. FIG Working Week, Strategic Integration of Surveying Services, Hong Kong, 2007.

[11] P. A. Pam, "Climate change and the information technology," Journal of Science and Technology, vol. 5, no. 1, pp. 64-80, 2007.
[12] J. Hansen, M. Sato, and R . Ruedy, "Perceptions of Climate Change: The New Climate Dice," 2012, http://globalwarmingsowhat.com/warm-cool-/loaded-temps-dice-since.pdf.

[13] R. J. Bord, A. Fisher, and R. E. O'Connor, "Public perceptions of global warming: United States and international perspectives," Climate Research, vol. 11, no. 1, pp. 75-84, 1999.

[14] O. V. Rukevwe, "The science of climate change: implication for Africa," Journal of Arid Environment, vol. 7, no. 1, pp. 72-85, 2008.

[15] P. A. O. Odjugo, Perception of Climate Change in the Niger Delta Region of Nigeria, Paper Series 2011, Centre for Population and Environmental Development Policy, Benin City, Nigeria, 2011.

[16] M. A. Haque, S. S. Yamamoto, A. A. Malik, and R. Sauerborn, "Households' perception of climate change and human health risks: a community perspective," Environmental Health, vol. 11, no. 1, article 1, 2012.

[17] S. B. Capstick, N. F. Pidgeon, and M. S. Whitehead, "Public Perception of Climate Change in Wales: Summary findings of a survey of the Welsh Public conducted during November and December 2012," 2013, http://c3wales.org/wpcontent/uploads/2013/03/C3W-report-FINAL.pdf.

[18] P. A. O. Odjugo, "Some effects of gas flaring on the microclimate of yam and cassava production in Erhorike and Environs, Delta State, Nigeria," Nigerian Geographical Journal, vol. 5, no. 1, pp. 43-54, 2007.

[19] P. A. O. Odjugo, "The impact of gas flaring on rainwater quality and human health in Delta State," Knowledge Review, vol. 11, no. 7, pp. 38-46, 2005.

[20] Intergovernmental Panel on Climate Change, "The Climate System: An Overview of Climate Change. Contribution of Working Group 1 to the Third Assessment Report of the Intergovernmental Panel on Climate Change," 2005.

[21] P. N. Nyelong, "Global warming and global waters," Journal of Energy and Environment, vol. 17, no. 1, pp. 79-90, 2004.

[22] P. A. O. Odjugo, "Regional evidence of climate change in Nigeria," Journal of Geography and Regional Planning, vol. 3, no. 6, pp. 142-150, 2010.

[23] R. T. Watson, "The global environment: linking the sciences," in Partnerships for Global Ecosystem Management: Science, Economics and Law. Proceedings and Reference Readings from the 5th Annual World Bank Conference on Environmentally and Socially Sustainable Development, Held at the World Bank and George Washington University, Washington, DC, USA, October 1997, I. Serageldin and J. Martin-Brown, Eds., pp. 29-38, The World Bank, Washington, DC, USA, 1997. 

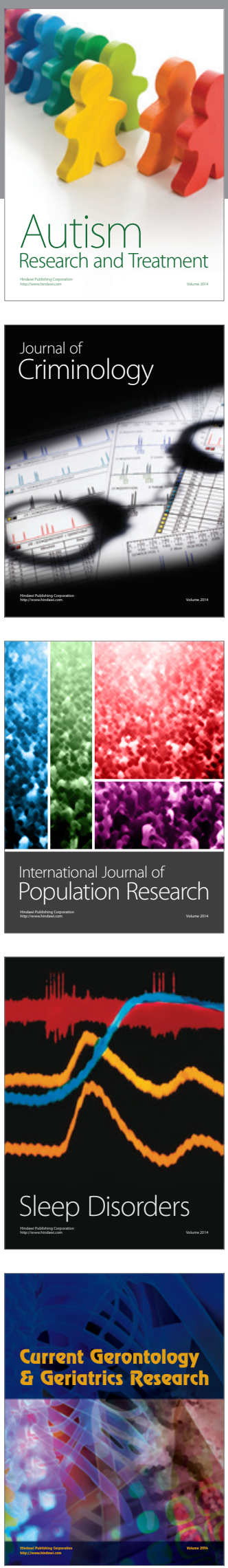
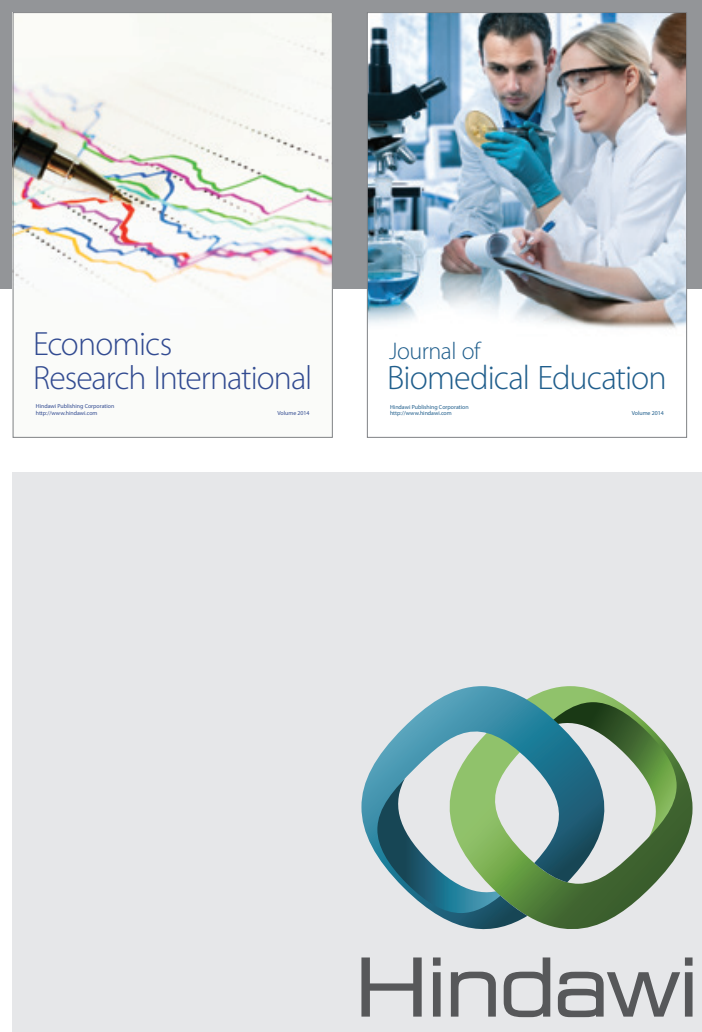

Submit your manuscripts at

http://www.hindawi.com
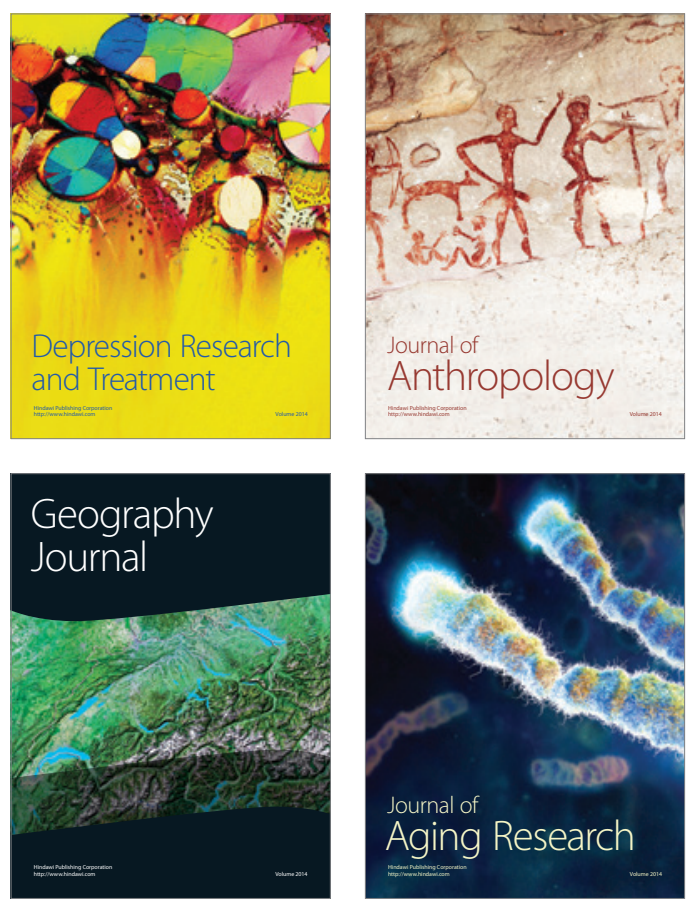
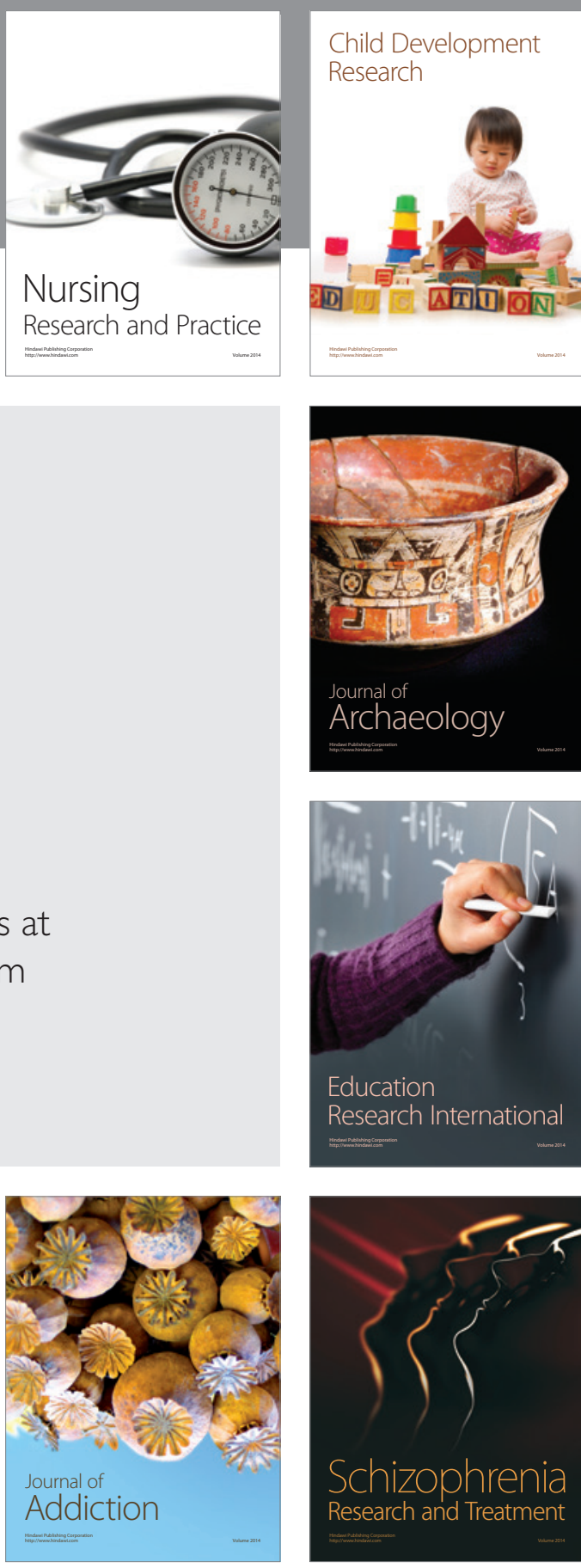

(D)
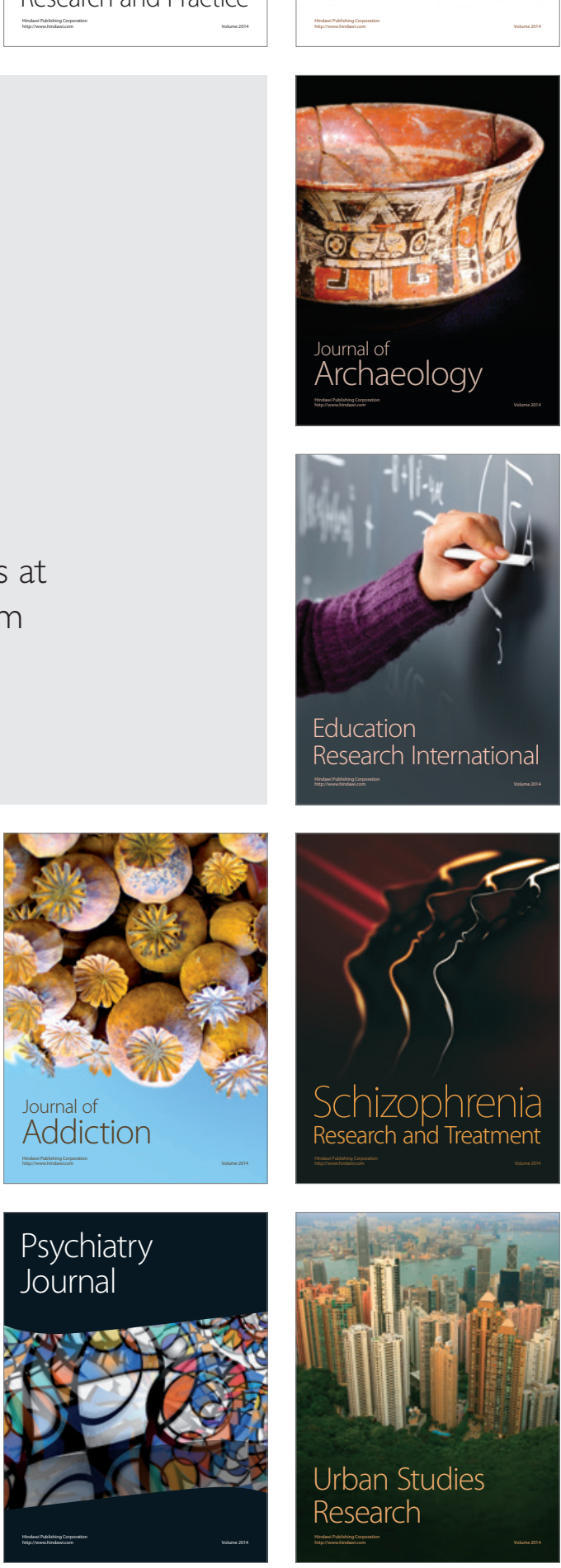